4.13 ASTRONOMICAL EFFORTS OF SAWAI JAI SINGH - A REVIEW

Virendra Nath Sharma

Department of Physics and Astronomy, University of Wisconsin Fox Valley, Menasha, WI 54952

USA

Abstract: Sawai Jai Singh, the statesman astronomer of 18th century India, designed instruments, built observatories, prepared $\mathrm{Z} \bar{i} j$, and sent a fact-finding scientific mission to Europe. His high-precision instruments were designed to measure time and angles with accuracies of \pm 2 second, and \pm 1 ' of arc respectively. The Sașṭhāmsa, a meridian dial with aperture, can still measure angles with precision of $\pm 1^{\prime}$ of arc. In the age of Newton and Flamsteed, Jai Singh and his associates remained medieval, in the tradition of Ulugh Beg, and did not initiate the new age of astronomy in the country. A complex interaction of poor communications, religious taboos, theological beliefs, national rivalries and plain simple human shortcomings are to be blamed for the failing.

INTRODUCTION

Sawai Jai Singh (1688-1743), the statesman astronomer of 18 th century India, undertook the "task (of revising planetary tables), which during a long period of time...since Mirza Ulugh Beg, no one had paid attention to" (See Reference $Z \bar{i} j$ Jadìd Muhammad Shăhi f.1). He constructed five observatories in different cities of north India and, after a considerable amount of labour of seven years or more, had a $\bar{Z} \bar{i} j$ prepared. Jai Singh's interests were varied, he collected books, had astronomical texts translated into Sanskrit, and sent a fact-finding scientific mission to Europe.

The object of this paper is to review Jai Singh's diversified efforts to rejuvenate astronomy in his country, and to assess him as an astronomer.

\title{
ASTRONOMICAL INSTRUMENTS
}

Masonry instruments

Jai Singh had been interested in instrumentation long before he decided to erect observatories, and as such, he collected literature on the subject. In 1716, he purchased two books on Turiya Yantra( File No.424/1, Jaipur records, Rajasthan State Archives). He initiated his ambitious program of observing the heavens with instruments of brass constructed according to Persian-Arabic school of astronomy (See Reference $Z \bar{i} j$ Jadid Muhammed Shăhi,$f .1$ ). However, the metal instruments did not measure up to his expectations, and he noted with disappointment 
that their axes soon wore down, displacing the centre and shifting the planes of reference. A reason for Jai Singh's difficulty could have been the fact that the technology of fabricating large metal instruments had not yet been developed in India. If the surviving specimens at the Jaipur Jantar Mantar are indicative of his attempts to construct metal instruments, it is obvious that his early instruments were too heavy, with no attention paid to eliminate the excessive weight. They were simply magnified versions of the small medieval instruments of the East that may still be seen in museums around the globe.

Jai Singh discarded his metal instruments in favour of ones of stone and masonry that he himself designed. De Bois, an eyewitness of his efforts, writes that the Raja prepared the models with his own hands (De Bois). Altogether, Jai Singh constructed 13 different types of instruments, ranging from a few $\mathrm{cm}$ to 24 meters in height, for his observations at Delhi, Jaipur, Varanasi, Ujjain and Mathura (Sharma,V.N. 1987; Kaye 1918).' In 1981-82, the author spent several months studying Jai Singh's instruments at these locations, and noted that the instruments may be classified into three main categories, namely: 1 . instruments for laymen, 2. low-precision instruments, and 3. the high-precision instruments. The instruments such as Dhruva Pațikā and Narívalaya have been clearly designed with a layman in mind, and are of little value to a researcher. The instruments such as Jai Prakāsa and Rāma Yantra, on the other hand, belong to the medium-precision category.

Jai Prakāśa is a multipurpose device and has a varying degree of accuracy. The Jaipur instrument, for instance, measures time with an uncertainty of $\pm 1 / 2$ to $\pm 1 \mathrm{~min}$. and the zenith distance and declination both with uncertainty of $\pm 3^{\prime}$ of arc. The uncertainty in the measurement of azimuth and right ascension could be anywhere from $\pm 3^{\prime}$ to $\pm 1 \mathrm{deg}$.

Despite the fact that Jagannath lauded the Jai Prakása as the finest of instruments, its utility is rather limited for the kind of precision Jai Singh had in mind (Sharma, R.S. 1967). The instrument is a good teaching tool nonetheless, displaying the relationship between the local and the equatorial systems of coordinates. Its ability to indicate the approach of a sign on the meridian is quite valuable to a Hindu astrologer.

The Räma Yantra, another of his low-precision devices, is most sensitive near the $45^{\circ}$ marks around the base line of its vertical walls. The theoretical accuracy of the Jaipur yantra is \pm 1 ' or arc for the angles of $40^{\circ}-50^{\circ}$. However, due to the finite width of the penumbra associated with the shadow of the pillar, the accuracies of this order ars not possible in practice. And as such, a precision of \pm 6 ' is the most that one can expect with this instrument ${ }^{1}$. For the zenith angle readings, the accuracies deteriorate at a rapid rate to $\pm 1^{\circ}$ or worse, as the angle approaches zero. 
The Samrāța Yantra and the Șașthāmsa both belong to the third category, that of high-precision instruments, and are the two most sensitive instruments indeed. The Samratta of Jaipur is apparently designed to measure time with precision of \pm 2 second, right ascension $\pm 15^{\prime \prime}$ of arc, and declination \pm 1 ' of arc. With this instrument, an accomplished observer can measure time with at least \pm 3 second, and the two angles with \pm 1 ' pf arc accuracies, provided the instrument is constructed properly. However, the instruments of Jaipur and Delhi both suffer from a number of constructional defects. As a result, the time measurement accuracy for the Jaipur instrument ranges between \pm 10 and \pm 90 seconds, depending on the section of the instrument used. Similarly, the uncertainty in declination measurements could be anywhere from \pm 1 ' to $\pm 15^{\prime}$ of arc. With his Samrätas Jai Singh seems to have measured time with a greater accuracy than the instrument of Jaipur is capable of today.

The Șașthāmsa of Jaipur is the only sensitive instrument of Jai Singh's that still maintains its intended accuracy of \pm 1 ' of arc. In 1981-82, the author took numerous readings with this instrument, and after becoming familiar with the device, his readings began to fall within the intended uncertainty. On December 23, 1981, for example, he measured the apparent declination of the meridian sun as $23^{\circ}: 25^{\prime} \pm 1^{\prime}$. This result compares well with the calculated value of $23^{\circ}: 26^{\prime}$ for the day.

Jai Singh did not stop after having designed these two high-precision instruments, but continued on with his search for better ones. Accordingly, he sent a delegation to Europe in 1728 with one of its goals being to learn about the old and the new instruments for astronomical observations (Gazeta 1). He apparently intended to incorporate these instruments into his Jaipur observatory which, according to De Bois, was still being expanded at the time (De Bois).

The questions that the Raja addresses to Boudier also reflect his continued interest in instrumentation. "How is the longitude of the moon observed in its of meridian position, and with what instrument?" he wrote to Boudier in 1730-31 (Lettres, pp.610-11)

\section{THE TELESCOPE}

Though Jai Singh's instruments are nontelescopic, he was aware of the telescope and to some extent, of its potential as well. He had bought one at a cost of Rs.100. for his personal library (Tozis 3) In his $Z \bar{i} . j-i$ Muhammad Shāhi, while introducing a chapter, "The visibility of Moon", he states, "These rules are for naked-eye observations only, although the telescope is now being made in the country. The telescope enables one to see bright stars in broad daylight also--say around the noon hour. It also enables one to see the moon when there is hardly any light in it, or when its face is totally dark and invisible... The planet Saturn (through a telescope) appears oval in shape, an oval whose lower half is larger than the upper. Around the planet Jupiter there revolve four bright stars. On the face of the Sun there 
are spots, and the Sun rotates once on its axis within a period of one year" (See, Zij Jadid Muhammad Shahi $\bar{i}$, f.189). He goes on to add, "Since the telescope is not readily available to an average person, we are going to base our rules of computations for the naked eye only" (Zijj Jadid Muhammad Shāhi , f.189).

Thus the telescope was indeed available to Jai Singh and his astronomers, and they did use it to some extent at their observatories. In the astronomical endeavors of Jai Singh, it is not the telescope but the "telescopic sight" that is missing. His instruments are not designed to incorporate the telescopic sight. The author believes that the telescopic sight, which had been accepted only decades earlier by the astronomers of Europe, did not reach Jai Singh in time.

Jai Singh's statement regarding the shape of Saturn suggests that the telescope available to him were of inferior quality. His erroneous statement about the rotational period of the Sun indicates that at his observatories there was no sustained program of observing in general with the telescope. His lack of interest in telescopic observation, and that of his astronomers as well, is further indicated by the fact that Jagannath does not include the telescope among the yantras for an observatory (Sharma,R.S. 1967, Yantradhyāya).

\section{THE HINDU, MUSLIM AND EUROPEAN ASSISTANTS}

Jai Singh's early training as an astronomer had been under Hindu pundits, and they remained the mainstay of his program until the very end. "Brahmins observe day and night at Jaipur", Boudier wrote (Lettres, pp 307-308). In 1734 there were $20 \mathrm{Hindu}$ astronomers employed on daily wages at the observatory of Jaipur alone (Tozis 1). Keval Ram and Jagannath were his principal Hindu Jyotisisis.

Jai Singh's interest in Islamic and European astronomy, and his patronizing of Muslim nujumis and firangis developed somewhat later, i.e., after 1715. An inventory of his library taken in 1715 shows Sanskrit books only (File No. 424/1, Jaipur records, Rajasthan State Archives). However, soon thereafter, Jai Singh started collecting Persian-Arabic works, and began patronizing the predominantly Muslim astronomers of the Persian-Arabic school. The involvement of Muslim astronomers in his program peaked around 1725 and then tapered off until the end of his career (Dastur Kaumvär). Jai Singh's most decorated nujümi was Dayanat Khan (Dastur Kaumvār, 19, p.563). The gifts and honors received by Dayanat Khan from the Raja suggest that he remained associated with him for over two decades. In 1718, he received his very first gift of Rs.500 from the Raja. The final record of him receiving a gift is in 1739 .

Abdul Khair, alias Khair Allah, is said to have been one of his influential consultants (Brindäban). However, the author did not see any record of gifts or honors received by Khair Allah in the Rajasthan State Archives. The Archives mention a dozen or so other nujumis, however, receiving gifts from the Raja. It is reasonable to assume that a team 
of these astronomers wrote the $Z \bar{i} j-i$ Muhammad Shāhi under the direction of Jai Singh.

As the involvement of Muslim nujümis in his astronomical activities lessened, the involvement of Europeans-primarily of Catholic faithincreased, reaching a peak around 1733 (Dastur Kaumvär, 18, 20; Tozis 2). The Europeans played the role of conveyors of European knowledge to the Raja. Accordingly, it was they who led a delegation to Europe, procured texts and instruments, translated de La Hire's tables, and carried out mathematical computations. However, the knowledge the Europeans brought to Jaipur had already become outdated in Europe, for it included neither the theories of Galileo, Kepler or Newton; nor the instruments such as the sextant employed by Flamsteed (Sharma,V.N. 1987; Kaye 1918).

\section{DELEGATION TO EUROPE}

In 1727-28, Jai Singh dispatched a scientific delegation to Europe after learning that "the business of observatory was being carried on in Europe". The delegation, the very first of its kind, led by Fr. Figuerado, reached Portugal in January of 1729 (Gazata 2). The Lisbon Gazette of March 10, 1729, reports that the delegation had come to the country to resolve questions regarding the astronomical tables used in Portugal and India, and to learn about the new and old instruments in astronomy (Gazeta 1).

Although the news of the delegation's arrival in Lisbon was duly published in the Paris Gazette, there is no mention of its arrival in Paris. The London papers are also silent about the delegation visiting their city. Apparently, the delegation never travelled to those places where the most advanced work on the subject was being carried out at that time. Surprisingly, the records of Coimbra University, the only institution of higher learning in Portugal at the time, say nothing about the delegation reaching their campus either.

The delegation returned in 1730 with some instruments, books on mathematics, and astronomical tables-including the one by de La Hire published in 1702. It is interesting to note that the delegation did not bring back the tables of Flamsteed published in England, which were the most accurate ones by then. In retrospect, the delegation produced very little.

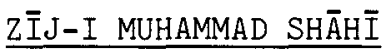

Jai Singh's stated objective had been to produce a set of improved astronomical tables. The tables, drawn up by a team of observers and nujumis, as mentioned earlier, and completed sometime between 1727 and 1735, were dedicated to the reigning emperor Muhammad Shah. The tables are, therefore, called $z \bar{i} j-i$ Muhammad Shāhī--the astronomical tables of Muhammad shah. Z $\bar{i} j-\dot{i}$ Muhammad Shāhì, henceforth abbreviated as ZMS, is a 400-page long traditional work on astronomy, of which a dozen copies survive to this day. 
After comparing five different copies of the ZMS, the author has concluded that there were at least two editions of this book ${ }^{2}$. The often-reported British Museum copy belongs to the second edition. Further, there were three commentaries said to have been written on the $Z_{M S}{ }^{3}$. To the world of astronomy at large, the ZMS is of little use; it had been superseded by better tables in Europe even before it was published. However, to the traditional scholar of the country, to whom Western science was out of reach, it remained a valuable resource for generations. The British Resident of Jaipur, J.P. Straton, writing in 1885 , pointed out that the ZMS was still being used there at that time (Purohit Hari Narayan Collection).

Recently, it has been reported that "all the tables of the $2 \bar{i} j$ concerning the Sun, Moon and planets are taken from de La Hire's work... They in no way depend on observations made in India" (Mercier 1984). We have not yet completed our analysis of the ZMS tables. Nonetheless, on the basis of the work done so far, we have reservations regarding the conclusions drawn in the paper.

\section{CONCLUSION}

For the sake of rejuvenating astronomy in his country, Jai Singh expanded a great deal of energy as well as his personal fortune, and yet he failed to initiate the new age of astronomy in India.

However, it would be unfair to conclude, therefore, that he is solely to blame for this fact. The means of communication were still in primitive stages in the early 18th century, and played a greater role in keeping the Raja ignorant of the contemporary astronomy of Europe than is generally realized. Secondly, a complex interaction of intellectual stagnation, religious taboos, theological beliefs, national rivalries, and the simple human failings of his associates also share the blame to certain extent ${ }^{4}$

Jai Singh's primary interest had been lunar phenomena. And for this, he made the best use of the technology available to him, the technology of building large masonry and stone structure which was highly developed in the country. As pointed out earlier, the great Samratas of Jaipur and Delhi are both capable of achieving a precision of $\pm i$, of arc--the limit for the unaided eye. Further, Jai Singh approached his selfappointed task of updating planetary tables with an open mind, and kept this attitude alive throughout his career. If De Bois can be believed, the Raja was ready to set aside all other tables if a better one were available (De Bois).

Jai Singh's accomplishments were mediaeval in retrospect, but his outlook was quite modern. For him the scientific knowledge had no religion or nationality. His efforts were truly secular; astronomers of all faiths participated in it--a fact that alone is no small compliment to a ruler born in an environment and age of intolerance and bigotry. 


\section{ACKNOWLEDGEMENT}

The author expresses his thanks and appreciation to Anu Sharma for helping him prepare the manuscript of this paper.

\section{NOTES}

1 By superimposing the shadow of a cross-hair on the penumbra one can achieve accuracies better than $\pm 6^{\prime}$ of arc. However, it is debatable if Jai Singh's astronomers used such a method.

2 The copies consulted by the author were from the following sources: (1) The British Lib., Ref. T, (2) Raza Lib. Rampur, No.1221, (3) Andhra Pradesh State Archives, Hyderabad, Riyazi 300, (4) Sawai Man Singh II Museum, Jaipur and (5) Azad Lib. Aligarh. The Raza library copy belongs to the first edition.

3 The commentaries were written by: (1) Khairallah See Jaunpuri G.H., (1835). p.579; Khan Gori,S.A., (1980).

4 For example: Jai Singh's Brahmin pundits would not go to Europe because of a religious taboo against "crossing the ocean". The Europeans (primarily the Jesuits) had rejected Kepler and Newton because of their theological beliefs. The national rivalries in Europe prompted the Portuguese to keep valuable contacts with a powerful prince of the East all to themselves. Some of these points have been further elaborated by the author in: Sharma,V.N. 1982a, 1982b \& 1984).

\section{REFERENCES}

Brindaban, Safina-i Khusgo, f'.123, Khudabaksha Lib., Patna.

Dastur Kaumvār, 18, $19 \& 20$, Jaipur State, Rajasthan State Archive, Bikaner.

De Bois, Joseph. Introduction to de La Hire's Tabulae astronomicae, ms., Sawai Man Singh II Museum, Jaipur.

Gazeta de Lisboa occidental (in short Gazeta) (1) March 10,1729, p.80, (2) Jan.20, 1729, p.24.

Jām-i Bahadur Khāni by Jaunpuri,G.H., p. 579, Calcutta, 1835; as quoted by Khan Gori, S.A.

Jaunpuri,G.H. (1835). Jām-i Bahādur Khänì, p.579, Calcutta.

Kaye,G.R. (1918). The Astronomical Observatories of Jai Singh,Calcutta. Reprint 1973, Indological Book House, Delhi.

Khan Gori,S.A. (1980). Impact of Modern European Astronomy on Jai Singh, Indian Journal of History of Science, 15, 50-57.

Lettres édifiantes et curieuses (1843) (in short Lettres) tome deuxieme, Paris.

Mercier,R. (1984). The astronomical Tables of Rajah Jai Singh Sawai, Indian Journal of History of Sciences, 19(2), 143-171.

Purohit Hari Narayan Collection, No.309/10, Rajasthan Oriental Research Institute, Jaipur, Rajasthan, India.

Samrāta Siddhānta of Jagannath Samrata.For ed. see Sharma,R.S. (1967). 
Sharma,R.S. (1967). Ed. Samräța Siddhānta of Jagannath Samrat, 2 1032, Indian Ins.Astro.Sanskrit Research, Reprint 1967, New Delhi.

Sharma,V.N. (1982a). Jai Singh, His European astronomers and the Copernican Revolution, Indian Journal of History of Science, 17 (2), 333-344.

- (1982b). The Impact of Eighteenth Century Jesuit Astronomers on the astronomy of India and China, Indian Journal of History of Science, 17 (2), 345-352.

- (1984). Jesuit Astronomers in Eighteenth Century India, Archives Internationales D'Histoire Des Sciences, 34 , 199-107.

- (1987). The Astronomical Endeavours of Jai Singh, Interaction between Indian and Central Asian Science and Technology in Medieval Times, Indian National Science Academy, New Delhi.

Tozis (1) Bundles Imarat Khana, Jaipur State, V.S. 1791, Rajasthan, State Archives, Bikaner. (2) Daftar Nushkha Punya, V.S. 1770-1797, Jaipur State, Rajasthan State Archives, Bikaner. (3) Pothikhana, Jaipur State, V.S. 1800, Rajasthan State Archives, Bikaner.

Zïj Jadīd Muhammad Shăhi M.S. Add. 14370: f. 1. Dept. Orienteal MSS., The British Library, London, England. 